\title{
SOME CLINICO-PATHOLOGICAL STUDIES OF CATTLE SUFFERING FROM HEMOGLOBINUREA AND ANEMIA IN KAFR-ELGALABTA VILLAGE, MENOFIA GOVERNORATE, EGYPT
}

\author{
GALBAT S.A. \\ Department of Animal Medicine, Assiut University, Faculty of Veterinary Medicine, New Valley Branch, New Valley
} Governorate, Egypt.

Received: 8 November 2015; Accepted: 10 December 2015

\begin{abstract}
This study was carried out to evaluate some clinico-pathological changes in cattle suffering from haematourea and anemia in kafr-Elgalabta village, Menofia Governorate, Egypt. Seven crossbred cows, 3-5 year- old, presented to a private veterinary clinic with a history of parturition one month ago. The clinical signs observed and recorded as passing red colored urine since last 3 days. Animals were dull and depressed, completely anorectic with pale mucous membranes and milk yield reduced from seven liters to less than two liters. The red urine occurred about 4 weeks after parturition. Animals had been fed on a little concentrated diet with hay and Alfalfa Some Affected cows also show fever, diarrhea, and rapid respiration. Blood samples were collected from the seven cases and other samples were collected from 5 healthy cows with the same management program as control group, to determine haematological and biochemical changes during this period. Decreased erythrocyte count and hypophosphatemia were reported in the clinically affected cows. The laboratory results showed that the animals presented low phosphorus concentrations in the plasma, Animals clinically affected by heamoglobiuria showed low number of total red blood cells (TRBC). The values found for hemoglobin in the Control group were $10.7 \pm 1.8 \mathrm{~g}$.dL while the levels of the affected by heamoglobinuria were $7 \pm 1.5 \mathrm{~g}$.dL. No changes in the erythrocyte, hemoglobin or plasma phosphorus were observed in the control group.
\end{abstract}

Key words: Hemoglobinurea, Anemia, Cattle, Egypt.

\section{INTRODUCTION}

The importance and essentiality of $\mathrm{P}$ in ruminant diets worldwide is well established and probably is the nutrient, other than common salt $(\mathrm{NaCl})$, most frequently given as a supplement to grazing ruminants (McDowell 1985). Various criteria have been used as diagnostic aids in assessing the $\mathrm{P}$ status of grazing ruminants. The first known response to a dietary deficiency of $\mathrm{P}$ is a fall in the inorganic phosphorus fraction of blood plasma (Underwood 1981).

Phosphorus, in the form of phosphate, is an essential mineral required for energy metabolism, maintenance, and function of skeletal structure, reproductive function, and lipid transport (Pond et al., 2005). Phosphorus (P) is used in several body processes including critical energy pathways (ATP), cell signaling, and synthesis of cell membranes,

Corresponding author: GALBAT S.A.

E-mail address: yasserelnaker@yahoo.com

Present address: Department of Animal Medicine, Assiut University, Faculty of Veterinary Medicine, New Valley Branch, New Valley Governorate, Egypt.
RNA, DNA, and bone. Because $\mathrm{P}$ cannot be synthesized, these needs must be met from dietary sources. Because dietary $\mathrm{P}$ cannot be used with perfect efficiency, a portion of dietary $\mathrm{P}$ is excreted, where it is subject to runoff and entry into surface waters (Wu et al., 2003).

Post-parturient haemoglobinuria is a non infectious haemolytic syndrome of buffaloes and cattle which is characterized by ntravascular haemolysis, anaemia and haemoglobinuria (Akhtar et al., 2007a, b). The exact pathogenesis is not yet known however associated risk factors include ingestion of cruciferous plants, saponin from berseem, dietary phosphorous deficiency, decreased serum copper and selenium whereas increased molybdenum (Pirzada et al., 1989; Radostits et al., 2007; Neto et al., 2007; Brechbuhl et al., 2008).

Excess of molybdenum in soil and fodder reduces phosphorous contents of the body by interfering with its absorption from gastro-intestinal tract and increasing its elimination through urine (Akhtar, 2006). Hypermolybdenosis also induces copper deficiency leading to reduced activity of copper 
containing enzyme superoxide dismutase which is part of erythrocyte protection mechanism against oxidative stress. This process helps in rendering them vulnerable to Heinz body formation as a result of feeding on poisonous plants (Smith et al., 1975; Kahn and Line, 2005 and Radostits et al., 2007).

Post-parturient haemoglobinuria is a sporadic disease in high producing dairy cattle characterised by intravascular haemolysis, haemoglobinuria, and anaemia (Macwillims et al., 1982). The transition between late pregnancy and early lactation, from calving until a 3 to 4 week postpartum, is a high-risk period for the occurrence of the disease in the dairy cow. The risk is especially high around parturition (Jub et al., 1990; Moore et al., 1997 and Whitaker et al., 1999).

The inorganic phosphate level in the blood provided an indication of the dietary phosphate intake (Grunwaldt et al., 2005). The disease occurs within 30 day of calving, and it is usually seen in adult dairy cattle during their third to sixth lactation (Blood et al., 1989).

A variety of risk factors have been reported to be associated with this disease in different parts of the Pakistan (Khan and Akhtar, 2007; Akhtar et al., 2008) the cause of the disease was dietary phosphorus deficiency, ingestion of cruciferous plants, saponin from berseem, mineral deficiency and competition of mineral absorption (Radostits et al., 2007; Neto et al., 2007; Brechbuhl et al., 2008; Mohamed and El-Deeb, 2010). The disease is usually seen in adult dairy cattle during their third to sixth Lactation (Blood et al., 1989). Copper deficiency has been suggested as a possible etiology of PPH Cattle from dairy farms with a high incidence of PPH had low levels of copper in serum and liver (Smith et al., 1973). The acute disease (three to five days) can terminate in death or be followed by prolonged convalescence (two to eight weeks). Ketonuria and a depraved appetite may occur during recovery (Blood et al., 1989). In affected herds, lactating but clinically normal cows have been moderately hypophosphatemic (2-3mg/ dL); nonlactating cows usually have normal serum phosphorus concentrations (Blood et al., 1989).

Treatment protocol includes the animals received phosphorus supplementation and supportive treatment. The treatment protocol for animals were designated as Tonophosphan as a source of phosphorus $25 \mathrm{ml}$ intra venous daily with $500 \mathrm{ml}$ normal saline, glucose $5 \% \mathrm{IV}$, and $250 \mathrm{ml}$ from calphomag (ca, p, mg) preparation, and $200 \mathrm{~g}$ of sodium Di basic phosphate powder orally with ration daily, with other supportive treatment animal recovered after one week.

\section{MATERIALS AND METHODS}

\section{Animals}

A seven crossbred cows, 3-5 year- old, presented to a private Veterinary Clinic with a history of parturition four month ago with heamoglobinurea considered as experimental group. Fife healthy cows with the same management program as control group.

\section{Samples}

For confirmative diagnosis blood samples were collected from the jugular vein before treatment. An aliquot of blood was placed into an EDTA-containing plastic tube for haematocytometry (Feldman et al., 2000). The rest of the blood samples were placed into glass tubes for the serum. These tubes were centrifuged and harvested serum was immediately frozen at $-20^{\circ} \mathrm{C}$ until analysis. The serum total protein (TP) (Henary el al., 1974), albumin (Alb) (Doumas et al., 1971), calcium (Ca), inorganic phosphorus (P), magnesium $(\mathrm{Mg})$, glucose (Trincler., 1961), were measured by an autoanalyser. The blood smears were stained by Giemsa's stain and then examined for blood parasites in erythrocytes under a light microscope.

\section{Statistical analyses}

Statistical differences were calculated according to the Student t-test with significance level at $\mathrm{P}<0.05$. All results were analyzed using the procedure of (SAS, 2004).

\section{RESULTS}

Table 1: Hematological and some biochemical parameters (mean \pm SD) in cattle's with post-parturient haemoglobinuria and control.

\begin{tabular}{lccc}
\hline Parameters & Clinically affected & $\begin{array}{c}\text { Clinically normal } \\
\text { (control) }\end{array}$ & $\begin{array}{c}\text { Reference range } \\
\text { Radostitis }(2007)\end{array}$ \\
\hline $\mathrm{P}(\mathrm{mg} / \mathrm{dl})$ & $3.1 \pm 0.79$ & $5.9 \pm 1.15$ & $5.6-6.5 \mathrm{mg} / \mathrm{dl}$ \\
\hline $\mathrm{Ca}(\mathrm{mg} / \mathrm{dl})$ & $7.8 \pm 0.36$ & $11.3 \pm 0.31$ & $9.7-12.4 \mathrm{mg} / \mathrm{dl}$ \\
\hline $\mathrm{Mg}(\mathrm{mg} / \mathrm{dl})$ & $0.75 \pm 0.28$ & $1.5 \pm 0.26$ & $1.8-2.3 \mathrm{mg} / \mathrm{dl}$ \\
\hline $\mathrm{Glucose}(\mathrm{mg} / \mathrm{dl})$ & $30 \pm 13.2$ & $50 \pm 12.4$ & $45-75 \mathrm{mg} / \mathrm{dl}$ \\
\hline $\mathrm{Alb}(\mathrm{g} / \mathrm{L})$ & $2.4 \pm 0.65$ & $2.5 \pm 0.97$ & $2.1-3.6 \mathrm{~g} / \mathrm{dl}$ \\
\hline $\mathrm{TP}(\mathrm{g} / \mathrm{L})$ & $5.6 \pm 1.0$ & $7.2 \pm 2.5$ & $5.7-8.1 \mathrm{~g} / \mathrm{dl}$ \\
\hline $\mathrm{TRBC}(\times 106 / \mu \mathrm{L})$ & $2.06 \pm 1.5$ & $6.08 \pm 3.2$ & $5-10(\times 106 / \mu \mathrm{L})$ \\
\hline $\mathrm{Hb}(\mathrm{g} / \mathrm{dl})$ & $7 \pm 1.5$ & $10.7 \pm 1.8$ & $8-15 \mathrm{~g} / \mathrm{dl}$ \\
\hline
\end{tabular}




\section{comparative between clinically affected and control}

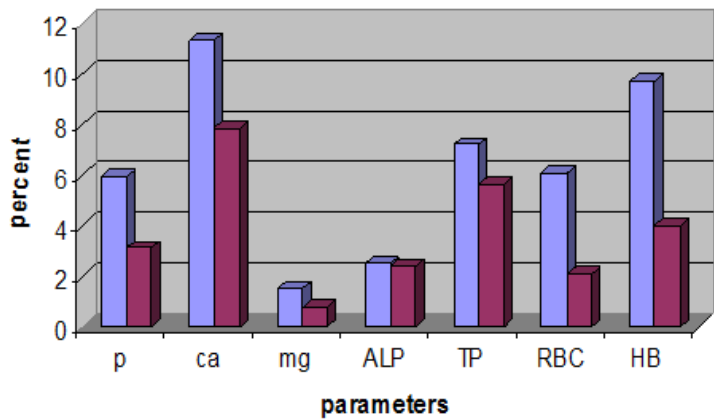

$\square$ control)
$\square$ Clinically affected

Figure 1: Haematological and some biochemical parameters (mean \pm SD) in the cattle with post-parturient hemoglobinuria and control.

\section{Comparative between cotrol and clincally affected animals}

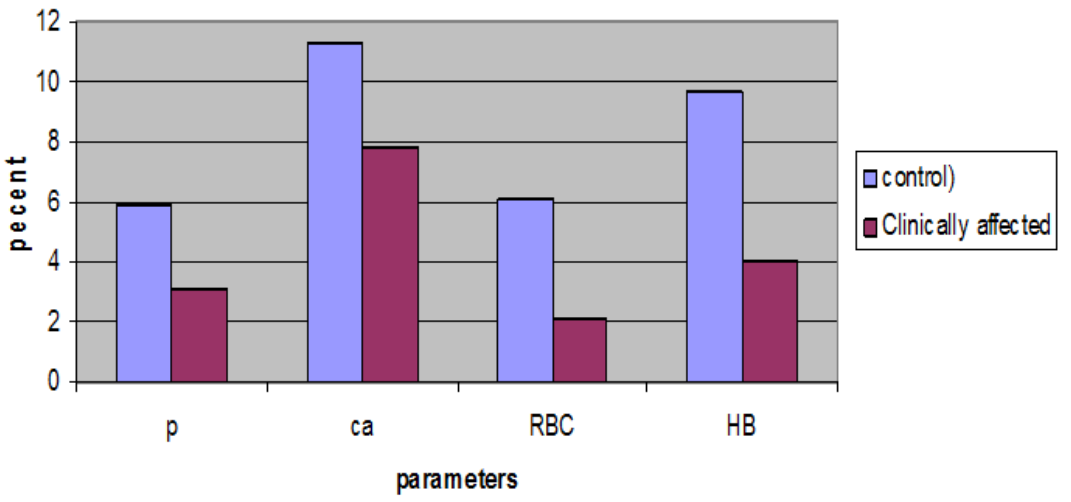

Figure 2: Comparison between recorded value in control and clinically affected animals.

In this cases reports, (Table 1) \& Fig $(\mathbf{1}, \mathbf{2})$ anorexia, depression, decreased ruminal movement, and milk production, moderate tachycardia, pale mucosa membranes, and haemoglobinuria were detected in caws. Moreover, determined that serum phosphorus was very low.

\section{DISCUSSION}

It is known that phosphorus deficiency can reduce the adenosine triphosphate content in red blood cells, influencing the structure and function of the cell, thereby increasing fragility and haemolysis, which may lead to acute haemoglobinuria (Wang et al., 1985). In this case, anorexia, depression, decreased ruminal movement, and milk production, moderate tachycardia, pale mucosa membranes, and haemoglobinuria were detected in studied cows. Moreover, we found serum phosphorus was very low. (Jub et al., 1990) reported that circulating oxidants may cause erythrocyte damage, which may be predisposed to hypophosphataemia. The phosphorus deficiency commonly occurs two to four weeks after calving. Stockdale et al. (2005) and fat cows had acute haemoglobinuria two to four weeks after calving. In the current study, detected that postparturient haemoglobinuria occurred about 6 weeks after calving. No blood parasites were detected in cattle with post-parturient haemoglobinuria. Phosphorus is an essential element for cellular function. It is absorbed in the small intestine and excreted either via the faeces or urine. Factors reducing the flow of saliva, such as anorexia, may cause increased losses of phosphorus via urine Reinhardt et al. (1988). Phosphorus is necessary for glycolysis, the formation of adenosine-triphospahte, and is also required for the maintenance of the erythrocyte cell membranes. Low serum inorganic phosphorus is a frequent finding in cattle with postparturient haemoglobinuria McCaughan, (1993). Stockdale et al. (2005) reported that marginal dietary phosphorus deficiency may leave cattle predisposed to acute haemoglobinuria. Thompson and Badger 
(1999) found that the serum phosphorus level in the cattle with haemoglobinuria was markedly decreased. In addition, Karapinar et al. (2006) also detected that the serum phosphorus level in cows with haemoglobinuria was very low $(0.5$ and $1.5 \mathrm{mg} / \mathrm{dL})$. In this study, the mean serum phosphorus level in 3-5 years old cattle's with post-parturient haemoglobinuria was lower Table (1) and Fig 1 and 2 . The cause of postparturient haemoglobinuria in this case may be related to dietary phosphorus deficiency. Since the cattle had been fed on a little concentrated diet of hay, and alfa-alfa which contains low amounts of phosphorus. Moreover, we reported that the serum glucose, $\mathrm{Ca}, \mathrm{Mg}$, TP, Alb and capacity concentrations in this case before and after treatment were within the normal range limits.

Decreased total erythrocyte count, hemoglobin concentration in affected cattle's indicating severe anemia which is attributed to intravascular haemolysis in this disease. The findings with respect to haematological parameters of affected cattle are in agreement with Dalir- Naghadeh et al. (2005); Akhtar (2006); Khan and Akhtar (2007); Radwan and Rateeb (2007) and Durrani et al. (2010).

Decreased serum inorganic phosphorous in affected cattle may be associated with prolonged feeding on cruciferous and or/toxic plants particularly berseem, heavy drainage of phosphorous through milk in high producing animals maintained on low phosphorous diets, low phosphorous rations with high calcium content and hypermolybdenosis. Low phosphorous diets with high calcium content cause hypophosphataemia by decreasing phosphorous absorption from the gastro-intestinal tract due to wider ratio of calcium and phosphorous whereas; excess of molybdenum also decreases phosphorous content by interfering with its absorption and increasing its elimination through urine Bhikane et al. (2004); Akhtar, (2006); Khan and Akhtar, (2007) and Dua, (2009).

From present study it can be concluded that addition of sodium dibasic phosphate to the diets of susceptible animals to haemoglobinurea (cattle after parturition), must ensure that the ratio between calcium and phosphorus not more than 2: 1 in the ration, with providing of treatment to clinically affected cases with phosphorus preparation as cafozal, tonophosphan and calgophos, especially in the winter season when the alfalfa (which is of poor in phosphorus) is the main meal for cows.

\section{REFERENCES}

Akhtar, M.Z.; Khan, A.; Khan, M.Z. and Javaid, A. (2008): Patho-biochemical changes in buffaloes (bubalus bubalis) suffering from parturient haemoglobinuria Pakistan Vet. J. 28 (3): 139-143.

Akhtar, M.Z.; Khan, A.; Sarwar, M. and Javaid, A. (2007a): Influence of soil and forage minerals on buffalo parturient haemoglobinuria. AsianAust. J. Anim. Sci., 20: 393-398.

Akhtar, M.Z.; Khan, A.; Khan, M.Z. and Muhammad, G. (2007b): Haemato-biochemical aspects of parturient haemoglobinuria in buffalo. Turkish J. Vet. Anim. Sci., 31(2): 119-123.

Akhtar, M.Z.; Khan, A.; Zaman, T. and Ahmad, N. (2006): Some clinico-epidemiological and biochemical observations of parturient haemoglobinuria in Nili-Ravi buffaloes (Bubalus bubalis). Pakistan Vet. J., 26 (4): 151-156.

Bhikane, A.U.; Anantwar, L.G.; Bhokre, A.P. and Narladkar, B.W. (2004): Incidence, clinicopathology and treatment of haemoglobinuria in buffaloes. Indian Veterinary J. 81(2): 192-197.

Blood, D.C.; Radostits, O.M. and Hendorsen, B.R. (1989): Veterinary Medicine Edited by Baillere Tindal, London.

Brechbuhl, M.; Meylan, M.; Kunz-Kirchhofer, C.; Bodmer, M.; Michel, A. and Kaufmann, T. (2008): Post-parturient haemoglobinuria in cows kept in the Swiss Alpine region. Tierarztliche Praxis Ausgabe G: Grosstiere Nutztiere 36 (4): 236-240.

Dalir-Naghadeh, B.; Seifi, H.A.; Asri-Rezaei, S. and Pilevary, N. (2005): Post-parturient haemoglobinuria in Iranian river buffaloes: a preliminary study. Comp. Clin. Pathol. 14: 221-225.

Doumas, B.T.; Watson, W.A. and Biggs, H.G. (1971): Albumin standards and the measurement of serum albumin with bromocresol green. Clin. Chim. Acta., 31: 87-96.

Dua, K. (2009): Importance of micronutrients and relevance of their supplementation in buffaloes. Pakistan J. of Zoology, supplementary series, number 9: 541-549.

Durrani, A.Z.; Kamal, N.; Shakoori, A.R. and Younus, R.M. (2010): Prevalence of post parturient haemoglobinuria in buffalo and therapeutic trials with toldimfos sodium and tea leaves in Pakistan. Turk. J. Vet. Anim. Sci. 34 (1): 45-51.

Farquharson, J. and Smith, KW. (1938): Postparturient hemoglobinuria of cattle. J. Am. Vet. Med. Assoc; 93: 37-39.

Feldman, B.F.; Zinkl, J.G. and Jain, Schalm's, N.C. (2000): Veterinary hematology. 5.ed. Lippincott Williams and Wilkins, 787p.

Grünwaldt, E.G.; Guevara, J.C.; Estevez, O.R.; Vicente, A.; Rousselle, H.; Alcuten, N.; Aguerregaray, D. and Stasi, C.R. (2005): Biochemical and haematological measurements in beef cattle in Mendoza Plain Rangelands (Argentina). Trop Anim Health Prod, 37: 527-540. 
Henry, R.J.; Cannon, D.C. and Winkelman, J.W. (1974): Clinical Chemistry, Principles and Techniques, $2^{\text {nd }}$ edition, Harper and Row, pp: 525.

Jubb, T.F.; Jerrett, I.V.; Browning, J.W. and Thomas, K.W. (1990): Haemoglobinuria and hypophosphatemia in postparturient dairy cows without dietary deficiency of phosphorus. Australian Veterinary Journal, 67: 86-89.

Kahn, C.M. and Line, editors, S. (2005): The Merck Veterinary Manual, 9th edition. Merck and Co., Inc. Whitehouse station, N.J., U.S.A., 816 p.

Karapinar T.; Dabak M. and Kırbas, A. (2006): İki inekte tespit edilen puerperel hemoglobinüri ve tedavisi. Dogu Anadolu Arastırma Dergisi, Türkiye, 2: 7-10.

Khan, A. and Akhtar, M.Z. (2007): Hematobiochemical and clinico-epidemiological aspects of parturient haemoglobinuria in NiliRavi buffaloes. Ital. J. Anim. Sci. 6 (Suppl. 2): 953 - 956. Montiel L., Tremblay A., Girard V., Chorfi Y. 2007. Preanalytic factors affecting blood in organic phosphate concentration in dairy cows. Vet Clin Pathol, 36: 278-280.

Macwillims, P.S.; Searcy, G.P. and Bellamy, J.E.C. (1982): Bovine post-parturient haemoglobinuria. Canadian Veterinary Journal, 23: 309-312.

McCaughan, C.J. (1993): Postparturient haemoglobinuria. In: Current Veterinary Therapy 3. Food Animal Practic. Edited by J.L. Howard Harcourt Brace Jovanovich Inc., Philadelphia, pp. 323-326.

McDowell, L.R. (1985): Nutrition of Grazing Ruminants in Warm Climates. Academic Press Inc: New York.

Mohamed, MG. and El-Deeb, WM. (2010): Lecithin cholesterol acyltransferase (LCAT) activity as a predictor for ketosis and parturient haemoglobinuria in Egyptian water buffaloes. Res. Vet. Sci., 88: 20-25.

Moore, F. (1997): Serum chemistry profiles in dairy cows - A herd management tool. Veterinary Medicine, 92: 986-991.

Neto, J.D.B.; Oliveira, C.M.C.; Duarte, M.D.; Albernaz, T.T.; de, C.A. Júnior, O.; Correa, G.R. and Correa, F.R. (2007): Phosphorus deficiency in buffaloes in the state of Paras, Northern Brazil. Ital. J. Anim. Sci. 6 (Suppl. 2): 971-973.

Pirzada, W.H.; Hussain, M. and Khan, K.N.M. (1989): A note on parturient haemoglobinuria in buffaloes. J. of Animal Health and Production 9: 20-22.

Pond, W.G.; Church, D.C.; Pond, K.R. and Schoknecht, P.A. (2005): Basic Animal Nutrition and Feeding. 5th ed. John Wiley and Sons Inc., Hoboken, NJ.
Radostits, O.M.; Gay, C.C.; Hinchcliff, K.W. and Constable, P.D. (2007): Veterinary Medicine: A Textbook of the Diseases of Cattle, Sheep, Pigs, Goats and Horses, 10th Ed. Elsevier's Health Sciences 1600 John F. Kennedy Boulevard, Suite 1800, Philadelphia, PA 19103 - 2899, U.S.A. $1682-83$ p.

Radwan, M.E. and Rateb, H.Z. (2007): Clinical, haematological and some biochemical variations hypophosphataemia in buffaloes before and after treatment at Assiut Government. BS. Vet. Med. J. 17 (2): 35-41.

Reinhardt, T.A.; Horst, R.L. and Goff, J.P. (1988): Calcium, phosphorus, and magnesium homeostasis in ruminants. Vet Clin North Am Food Anim Pract, 4: 331-350.

SAS, (2004): Statistical Analysis Systems. Version 9.2. SAS Institute, Cary, NC.

Smith, B.; Woodhouse, DA. and Fraser, AJ. (1975): The effects of copper supplementation on stock health and production. 2. The effect of parenteral copper on incidence of disease, haematological changes and blood copper levels in a dairy herd with hypocuprosis. $\mathrm{N} \mathrm{Z}$ Vet. J.; 23: 109-112.

Smith, B. (1973): Copper and molybdenum imbalance in relationship to post- aturient haemoglobinuria in cattle. N Z Vet. J. 21: 240.

Stockdale, C.R.; Moyes, T.E. and Dyson, R. (2005): Acute postparturient haemoglobinuria in dairy cows and phosphorus status. Australian Veterinary Journal, 83: 362-366.

Thompson, J.C. and Badger, S.B. (1999): Outbreak of post-parturient haemoglobinuria in an autumn calving dairy herd. Newzeland Veterinary Journal, 47: 180-183.

Trinder, P. (1961): Enzymatic colorimetric method for glucose dedermination. Ann. Clin. Biochem., 6: 24- 39.

Underwood, EJ. (1981): The Mineral Nutrition of Livestock (2nd edition). Commonwealth Agricultural Bureaux, London.

Wang, X.L.; Gallager, C.H.; Mcclure, T.J.; Reeve, V.E. and Canfield, P.J. (1985): Post-parturient haemoglobinuria: effect of inorganic phosphate on red cell metabolism. Research Veterinary Science, 39: 333-339.

Whitaker, D.D.; Goodger, W.J.; Garcia, M.; Perera, B.M.A.O. and Wittver, F. (1999): Use of metabolic profiles in dairy cattle in tropical and subtropical countries on small holder dairy farms. Preventive Veterinary Medicine, 38: 119-131.

Wu, Z.; Tallam, S.K.; Ishler, V.A. and Archibald, D.D. (2003): Utilization of phosphorus in lactating cows fed varying amounts of phosphorus and forage. J. Dairy Sci. 86: 33003308 . 


\section{بعض الدراسات الاكلينيكية على الحالات المرضية فى الماثية التى تعانى من نزول البول مدمم وفقر الدم في قرية

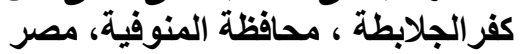

\section{صلاح عبد المحسن جلبط}

Email: yasserelnaker@yahoo.com

Assiut University web-site: www.aun.edu.eg

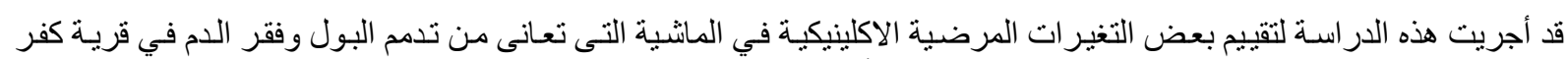

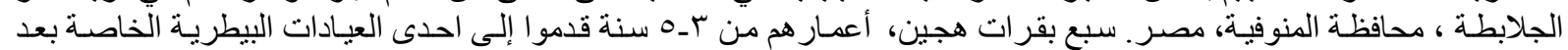

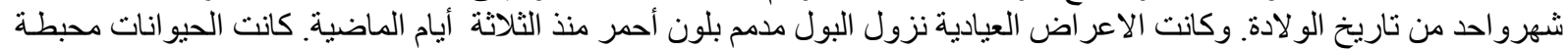

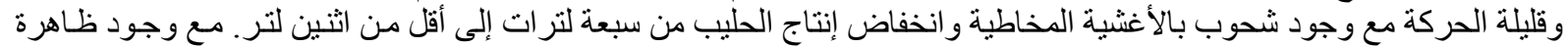

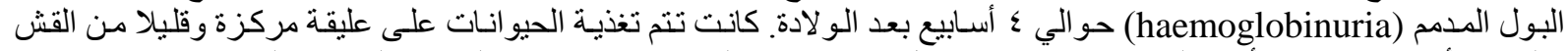

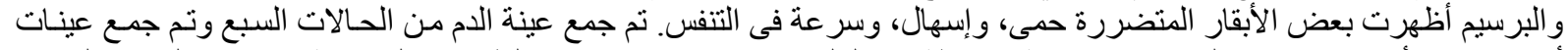

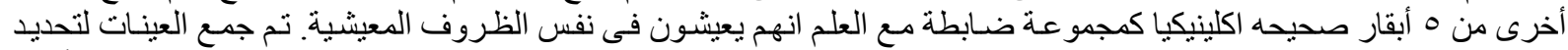

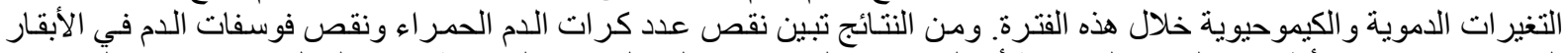

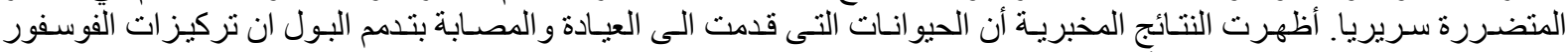

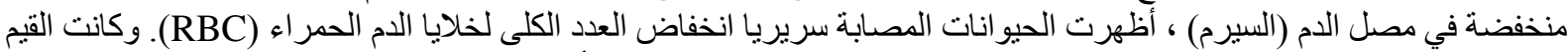

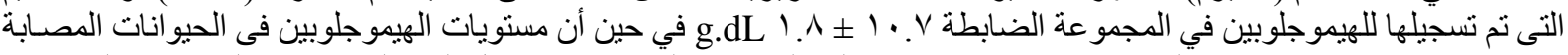

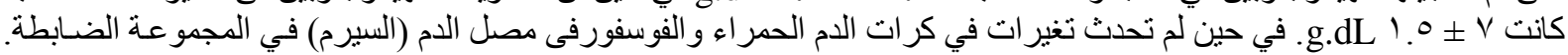

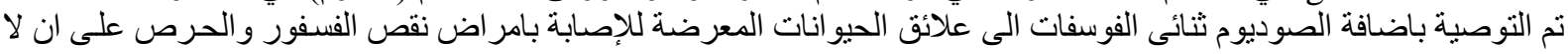

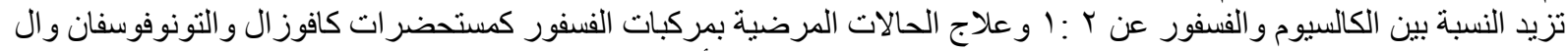
كالجوفوس وخصوصا فى موسم الثتاء و عندما يكون البرسيم (وهو من الأغذية الفقيرة بالفسفور) هو العلف الرئيسئى للابقار. 